\title{
SOLUTIONS TO PREVENT FINANCIAL CRISIS IN ISLAMIC ECONOMIC PERSPECTIVE: ANP APPROACH
}

\author{
Ascarya \\ Central Banking Education and Studies Department \\ Bank Indonesia \\ Jakarta, Indonesia \\ Email: ascarya@bi.go.id
}

\begin{abstract}
In the past two centuries financial crises have occurred one after another repeatedly since the first financial crisis in England 1825 until current ongoing global financial crisis triggered by the US subprime mortgage crisis in August 2007. These repeated man-made financial crises happened due to the transgressions of Allah's laws in financial dealings, especially in the abandonment of main pillars of Islamic financial system, namely prohibition of riba (usury or interest), prohibition of maysir (game of chance or speculation) and prohibition of gharar (excessive uncertainty), in their many forms, as well as due to misbehaviors of economic actors, poor governance and unsustainable fiscal system. The solutions taken have never touched their real root causes, so that financial crises have never subsided and have repeated with greater frequency and intensity affecting wider region. This study will apply soft system method Analytic Network Process (ANP) to provide Islamic solutions to prevent financial crisis which will be grouped into five clusters, namely: Behavior Control, External Control, Good Governance, Stable Monetary System and Sustainable Fiscal System. Each cluster will have six relevant elements obtained from literatures and in-depth interviews with several experts.

The ANP results show that solutions to financial crisis which stand out are STABLE \& JUST MONETARY SYSTEM, especially the prohibition of maysir and ribā; EXTERNAL CONTROL, especially Islamic economic union, capital flow management and Islamic free trade area; GOOD GOVERNANCE, especially establishment of hisbah institution and credibility; SUSTAINABLE \& JUST FISCAL SYSTEM, especially obligatory zakah system and idle asset distribution; and BEHAVIOR CONTROL, especially encouragement of infaq and shadaqah. Therefore, the prohibition of maysir and ribā in all forms should be done gradually in short/medium term to prevent future financial crisis, as well as to achieve stable financial system.
\end{abstract}

Keywords: Financial crisis, Islamic economic solutions, ANP

\section{INTRODUCTION}

\subsection{Background}

In the past two centuries financial crises have occurred one after another started from the first financial crisis in England 1825 due to the introduction of fiat money which has been overly printed and circulated without having sufficient gold or silver back up. Financial crisis in the past century started since the demise of gold standard regime in 1915. The crises have subsided in the return of gold standard under Bretton Woods Agreements in 1950-1972, with strict fixed exchange rate international monetary arrangements. The Bretton Woods era is known as a golden age, where personal income increases, the volume of world trade increases, investment increases, and international economic stability maintained. The Bretton Woods agreements finally collapsed in 1971, when the US unilaterally terminated the convertibility of US Dollar to gold. Following the collapse of Bretton Woods Agreements, financial crises have resurfaced more frequently. Since the collapse of Bretton Woods Agreements there have already been 431 financial crises (Laeven and Valencia, 2012) that covers 431 episodes of financial crises including 147 banking crises, 218 currency crises (10 episodes in 2008-2011), and 66 sovereign debt crisis, including 68 twin crises and 8 triplet crises (see 
figure 1.1). These financial crises happened not because of cyclical or managerial failures, but because of structural failures in various countries under very different regulatory systems as well as at different stages of economic development (Lietaer et al., 2009).

However, the conventional solutions taken only deal with the symptoms, not the root systemic causes of the financial crisis. Therefore, real solutions to the root causes of financial crisis should be determined to be implemented to resolve the repeated financial crisis and develop stable financial system directed toward the maximum achievement of just and distributive human wellbeing.

\subsection{Objective}

The objective of this study is to determine real solutions to prevent financial crisis from Islamic economic perspective targeting the elimination of the root causes of financial crisis, so that stable and just financial system can be developed to achieve Shari'ah objectives for the society, namely happiness and victory in this world and in the hereafter.

\section{Literature Review}

To find the real solutions to financial crisis one should understand the real root causes of financial crises from their origin. This section will discuss the origin of financial crisis and previous studies which support this argument.

\subsection{The Origin of Financial Crisis}

Financial crisis as we understand today is not really a new modern day phenomena, but it has been existed since pre-historic era. The origin of financial crisis can be distinguished into six different types which cause the crisis, namely: 1) crisis caused by natural phenomena (for example, Al Qur'an surah Yusuf [12]:46-49); 2) crisis caused by the debasement of currency which triggers currency crisis (for example, the firs financial crisis in England 1825; Peso crisis in Mexico 1994); 3) crisis caused by the creation of fractional reserve banking system which triggers banking crisis (for example, banking panics in US October 1930; banking crisis in Indonesia 1998); 4) crisis caused by the creation of sovereign external debt which triggers debt crisis (for example, the first sovereign debt default in Spain 1557; Greek sovereign debt crisis in 2010); 5) crisis caused by the creation of capital market which triggers stock market crash (for example, Tulip mania in Amsterdam 1636-37; Black Monday in Wall Street 1929); and 6) crisis caused by the creation of derivatives which triggers bankruptcy of banks (for example, Barings Bank bankruptcy in UK 1995; Bear Sterns bankruptcy in US 2008).

\subsection{Previous Studies}

There are many studies on current global financial crisis from Islamic economic perspective, although they are not as many as those of conventional economic perspective. The Task Force on Islamic Finance and Global Financial Stability, organized by Islamic Development Bank - IDB, published a report on Islamic finance and global financial stability (2010), which discusses the resilience of Islamic finance against global financial crisis. There is one special volume of International Journal of Islamic and Middle Eastern Finance and Management, volume 3 number 4 (2010) which comprises of 8 papers. There is a compilation book by Islamic Economic Research Center, King Abdulaziz University - IERC-KAU (2009), which includes 18 papers of prominent Islamic economic and finance scholars. There are also many studies from various journals which discuss financial crisis.

The solutions to financial crisis from Islamic perspective from these studies could be summarized in five groups, namely: 1) behavior control, including education-dakwah, enforcement and supervision of regulation in Islamic market conduct, self-control, avoid debt, and encouragement of infaq-sadaqah (Chapra, 2008; Iqbal and Khan, 2004); 2) external control, including disaster-crisis management, fair international trade, capital flow management, Islamic free trade area, Islamic economic union, and international gold standard (Khan and Thaut, 2008; Ali, 2006-2007; Meera and Larbani, 2004; Ahmed, 2001); 3) good governance, including transparency, credibility, accountability, internal control, establishment of hisbah institution, and assignment of the right man in the right place 
(Othman, et al., 2012; Smolo and Mirakhor, 2010; Khan, 2001); 4) stable monetary system, including prohibition of riba , international single currency system with gold (backed) standard, Islamic narrow banking system, prohibition of maysir, securities should be asset backed, and debit card to replace credit card (Othman, et al., 2012; Al-Masri, 2009; Obaidullah, 2005); and 5) sustainable fiscal system, including obligatory zakat system, redistribution of idle assets, Islamic tax system if necessary, balanced budget, inventory management of strategic commodities, and PLS domestic sukuk if necessary to finance infrastructure projects (Iqbal and Khan, 2004; Kahf, 2000; Oguz and Tabakoglu, 1991).

\section{Methodology}

This study will use qualitative method Analytic Network Process (ANP) in three steps. First, in-depth interviews with scholars and experts of Islamic economic and finance are conducted to fully comprehend the real root causes of financial crisis and determine the real solutions from Islamic economic perspective. Second, the results of the first stage are used to develop an appropriate ANP network and relevant questionnaires to gather the necessary data from seven scholars and experts of Islamic economic and finance. Third, ANP analysis is applied to prioritize Islamic economic solutions to prevent financial crisis. Overall results from seven experts can be obtained by calculating the geometric mean of their answers.

\subsection{Steps of Research}

Based on ANP methodology, the main steps of ANP modeling are: 1) Decomposition, which is the development of ANP network of the problem; 2) Measurement, which is pairwise comparisons on the elements and relative weight estimation of all dependence and feedback relationships in the ANP network; and 3) Synthesis, which includes construction and calculation of original unweighted supermatrix, weighted supermatrix, and limiting supermatrix (the global priority weights).

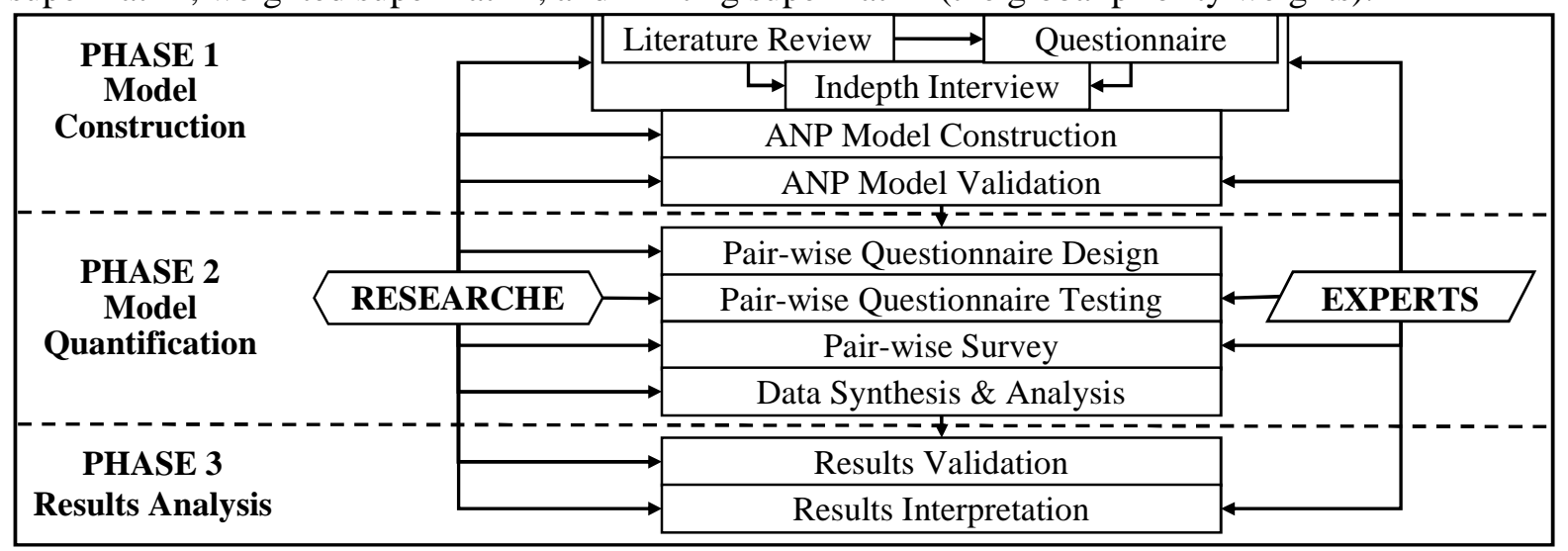

Figure 3.1 Steps of Research

This study comprises of several extended steps of main ANP modeling, which can be grouped into three phases. Phase 1 is model construction or decomposition to identify, analyze and structure the complexity of the problems into an appropriate ANP network, which includes: a) Literature reviews, questionnaires and in-depth interviews with experts and practitioners (Islamic bankers) to comprehend the problem fully; b) Construction of ANP network; and c) Validation of ANP network. Phase 2 is model quantification or pair-wise comparison, includes: a) Design pair-wise questionnaires in accordance with ANP network; b) Test the pair-wise questionnaires to respondents (experts and/or Islamic bankers); and c) Survey to respondents to fill out pair-wise questionnaires. Phase 3 is synthesis and results analysis, which includes: a) Data processing and synthesis using ANP software SUPERDECISIONS, as well as results analyses to calculate geometric mean and rater agreement; $b$ ) Validation of the results; and c) Interpretations of the results.

\subsection{Geometric Mean}


The Geometric Mean, which is a theorem in mathematics, is the unique way to combine group judgments. Instead of obtaining pairwise questionnaires from FGD consensus of all respondents, pairwise questionnaires of each respondent can be combined to obtain geometric mean consensus.

Geometric mean is a type of mean or average in mathematics, which indicates the central tendency or typical value of a set of numbers. To calculate geometric mean, the numbers are multiplied and then the $\mathrm{n}^{\text {th }}$ root of the resulting product is taken ( $\mathrm{n}$ is the count of numbers in the set). The geometric mean of a data set $\left\{a_{1}, a_{2}, \ldots, a_{n}\right\}$ is given by:

$$
\left(\prod_{i=1}^{n} a_{i}\right)^{1 / n}=\sqrt[n]{a_{1} a_{2} \ldots a_{n}}
$$

The geometric mean of a data set is less than or equal to the data set's arithmetic mean (the two means are equal if and only if all members of the data set are equal). This allows the definition of the arithmetic-geometric mean, a mixture of the two which always lies in between.

\subsection{Conceptual Framework}

The ANP model is structured into solutions from various sectors. Solutions will cover all root causes of financial crisis, which could be eradicated, prevented or controlled. Solutions could be divided into five clusters, namely: 1) behavior control; 2) external control; 3) good governance; 4) stable and just monetary system; and 5) sustainable and just fiscal system. Behaviors of economic actors which transgress Allah's laws could be avoided or controlled externally and internally by education and dakwah, regulations and their enforcement, as well as the implementation of Islamic behaviors in individual's consumption. External events could be controlled and managed by bilateral or multilateral agreement and cooperation, external regulation and control, as well as Islamic economic union and standard. Governance could implement the principles of Islamic good governance, establishment of hisbah institution, and assigning the right man on the right place. Monetary system could implement the principles of stable and just Islamic monetary system, including in Islamic financial products innovation, such as asset backed securities and the use of debit card (instead of credit card). Fiscal system could implement the principles of sustainable and just Islamic fiscal system, inventory system for strategic commodities and the use of PLS domestic if needed.

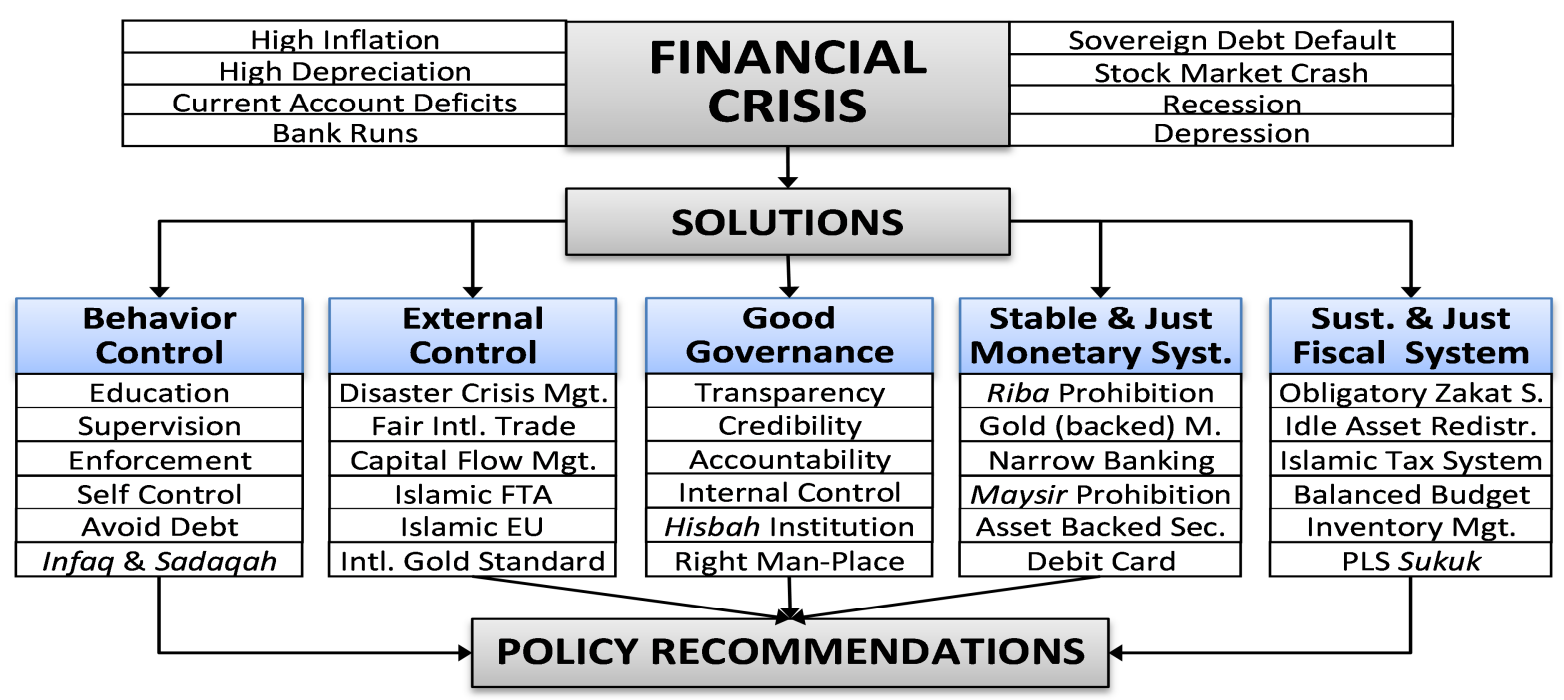

Figure 3.2 The Solutions to Prevent Financial Crisis

Based on the above conceptual framework, the corresponding ANP network for the solutions to prevent financial crisis can be seen in figure 3.3. 


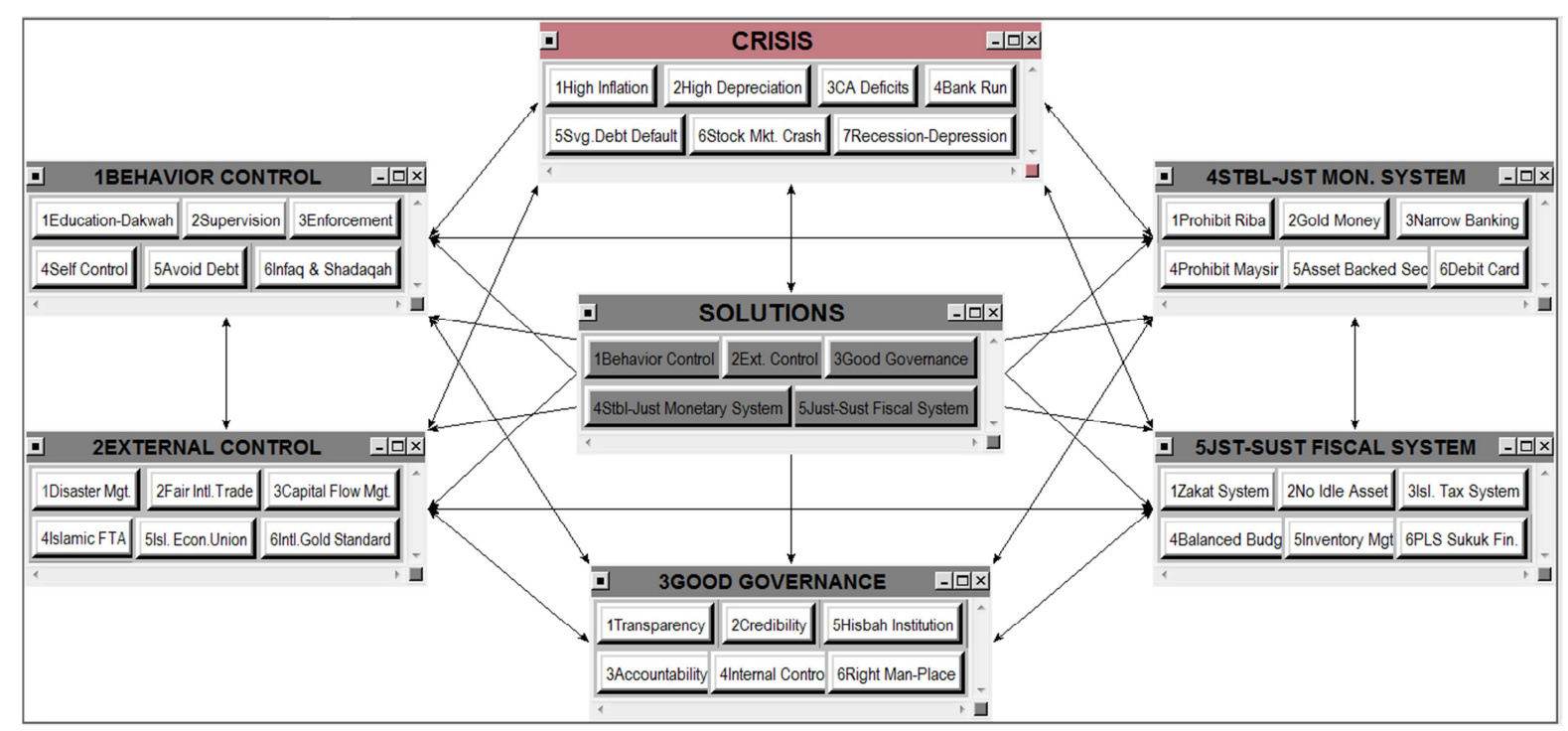

Figure 3.3 ANP Network for The Solutions to Prevent Financial Crisis

\section{Results and Analysis}

Table 4.1 in the appendix shows the summary results of ANP for all clusters, which are shown in two figures, i.e., 'normalized by cluster' and 'limiting'. Value in 'normalized by cluster' column shows relative value of each element to other elements in the cluster, where the total value of all elements in one cluster equals to one. Value in 'limiting' column shows relative values of each element to the entire network, where the total value of all elements in ANP network equals to one.

\section{[Insert Table 4.1]}

The general ANP results show that the main solutions to financial crisis from Islamic economic perspective (see figure 4.1) are Sustainable Fiscal System (0.251), Good Governance (0.219) and Stable Monetary System (0.209), followed by Stable Monetary System (0.209) and External Control (0.144).

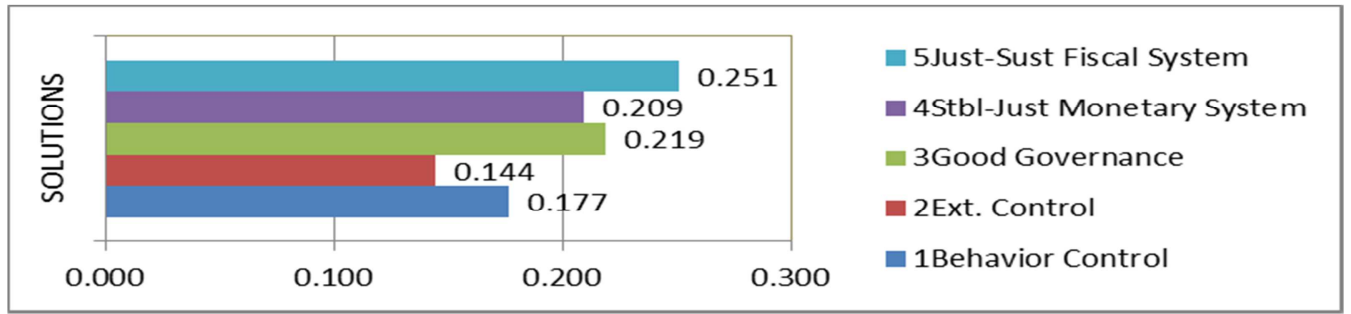

Figure 4.1 General Solutions to Financial Crisis

The detailed ANP results show that the most important (first-three) solutions to financial crisis from Islamic perspective (see figure 4.2) are prohibition of maysir or game of chance or speculation (0.0398), prohibition of riba or usury or interest (0.0353), and establishing Islamic economic union among OIC member countries (0.0342). The next most important (second-three) solutions are establishment of hisbah (or supervisory) institution (0.0324), establishment of obligatory zakat system (0.0308), and idle assets distribution (0.0308). Other important solutions to financial crisis are encouragement to give infaq \& shadaqah or charity (0.0307), capital flow management (0.0296), establishment of Islamic free trade area among OIC member countries (0.0296), and credibility of government and private officials (0.0289). In summary, solutions to financial crisis which stand out are STABLE AND JUST MONETARY SYSTEM, especially the prohibition of maysir and ribā; EXTERNAL CONTROL, especially Islamic economic union, capital flow management and Islamic free trade area; GOOD GOVERNANCE, especially hisbah institution and credibility; SUSTAINABLE AND JUST FISCAL SYSTEM, especially obligatory zakah system and idle asset distribution; and BEHAVIOR CONTROL, especially encouragement of infaq and shadaqah. 


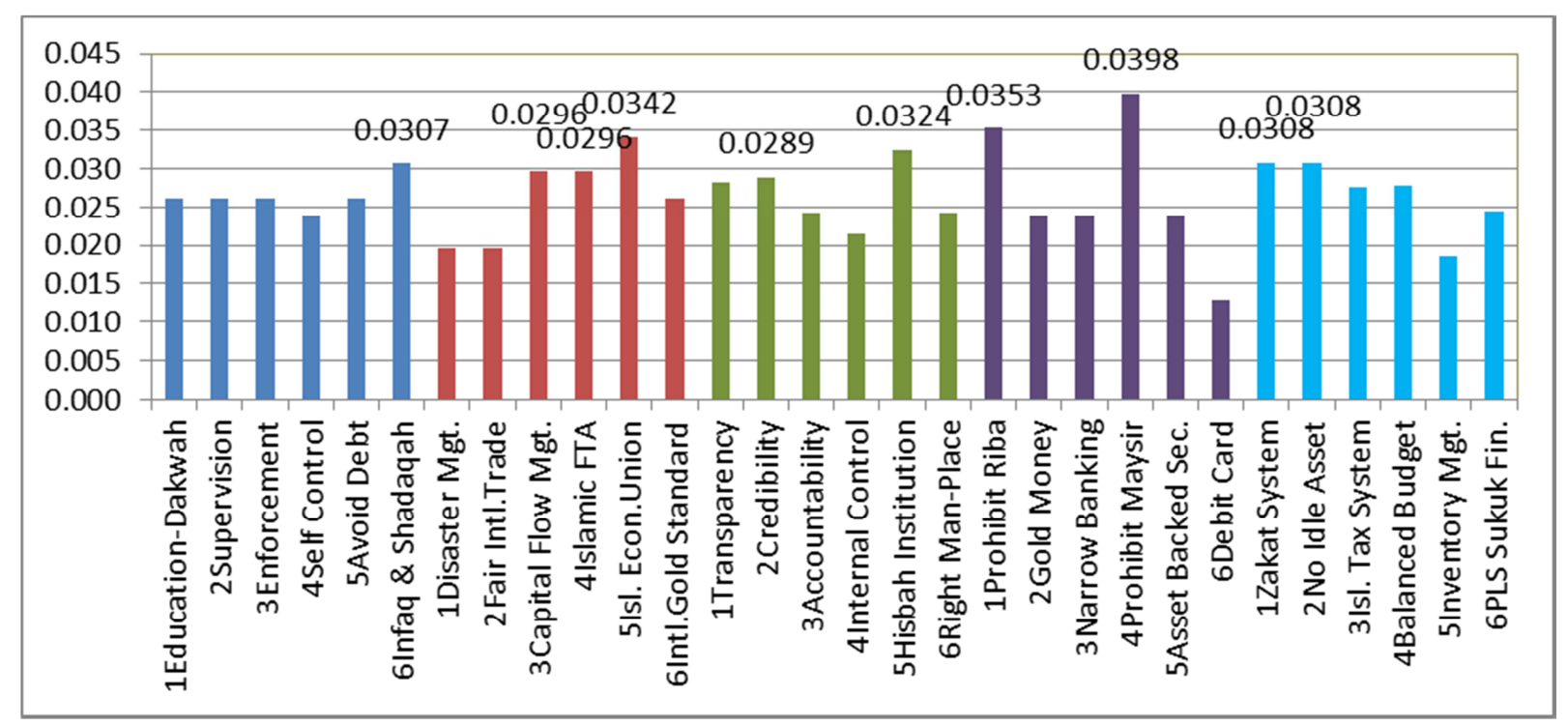

Figure 4.2 Detailed Solutions to Financial Crisis

The most important solutions to prevent financial crisis come down to the main pillars of Islamic economic and finance, namely, the prohibition of riba and the prohibition of maysir, which are parts of STABLE AND JUST MONETARY SYSTEM As stated in Ascarya and Iskandar (2013), riba could take the forms of: 1) interest system; 2) fiat money system; 3) fractional reserve banking system; 4) leverage system; 5) derivatives; and 6) credit card system, while maysir could take the forms of: 7) speculation in stock trading; 8) speculation in foreign exchange trading; 9) speculation in commodity trading; 10) speculation in real estates; and 11) other speculations in any market.

Riba is prohibited in several stages, in line with the readiness of the society of that era. In the first stage in Makkah, surah Ar-Rum (30:39) says that riba (interest) will deprive wealth from Allah's blessings, while sadaqah (charity) will raise Allah's blessings manifold. In the second stage in the early Madinah period, it is mentioned in surah An-Nisaa (4:161) that riba is severely condemned (which is in line with riba prohibition in previous scriptures) and those who take rib $\bar{a}$ are threatened with severe punishment from Allah. In the third stage in the second or third year of Hijrah, surah Ali Imran (3:130-133) enjoins Muslims who believe to keep away from rib $\bar{a}$, if they desire Islamic wellbeing. In the fourth stage close to the completion of Prophet's mission, surah Al-Baqarah (2:275-

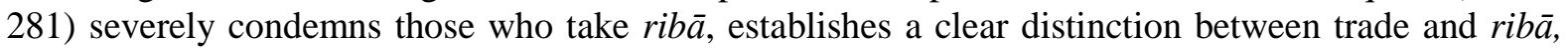
and requires Muslims to annul all outstanding riba anstructing them to take only the principal amount, and forego even this in case of the borrowers' hardship (Chapra, 1985).

Meanwhile, maysir is also prohibited by Al-Qur'an in several stages. In the first stage, gambling is considered as great sin which also contains some benefit, but the sin is greater than the benefit (Surah Al-Baqarah [2]:219). In the second stage, gambling is described as satan handiwork, so that believers should avoid gambling in order to be successful (Surah Al-Maidah [5]:90). In the last stage, gambling must be stopped and prohibited since it hinders someone from the remembrance of Allah and from the prayer (Surah Al-Maidah [5]:91). In modern era, maysir is not only present in gambling, but also present in many other sophisticated forms, such as stocks/financial assets trading to make capital gain, forwards, future and options contracts, derivatives products (such as Credit Default Swaps), etc.

\section{Conclusion and Recommendation}

\subsection{Conclusion}

The root causes or origins of financial crises could be traced back to several events, including: 1) natural phenomena; 2) debasement of currency; 3) creation of fractional reserve banking system; 4) creation of sovereign external debt; 5) creation of capital market; and 6) creation of derivatives. In 
addition, the development of financial markets and their derivative products have made speculation activities to flourish.

Viewed from Islamic economic perspective, the solutions of financial crisis are to stop all transgressions of Allah's law in all forms of financial dealings and replace them with Islamic alternatives available, including BEHAVIOR CONTROL of economic actors in financial and real markets, GOOD GOVERNANCE in public and private institutions, STABLE \& JUST MONETARY SYSTEM based on prohibitions of riba, maysir and gharar in all forms, and SUSTAINABLE \& JUST FISCAL SYSTEM which contains just, fair and non-exploitative policies. Another solution to financial crisis is EXTERNAL CONTROL which could lessen the impact of natural events (such as business cycle and natural disaster) and of man-made events (such as international currency system, political instability and social instability).

The general ANP results show that the main root solutions to financial crisis are SUSTAINABLE \& JUST FISCAL SYSTEM (especially, Obligatory zakah system and Redistribution of idle assets), GOOD GOVERNANCE (especially, establishment of Hisbah Institution and Credibility), STABLE \& JUST MONETARY SYSTEM (especially, Prohibition of Maysir and Prohibition of Riba), BEHAVIOR CONTROL of economic actors (especially, Encouragement of Infaq \& Sadaqah), and EXTERNAL CONTROL (especially, Islamic Economic Union, Islamic Free/Fair Trade Area and Capital Flow Management).

The detailed ANP results show that the most important (first-three) solutions to financial crisis from Islamic perspective are prohibition of maysir or game of chance or speculation (0.0398), prohibition of riba or usury or interest (0.0353), and the establishing Islamic economic union among OIC member countries (0.0342). The next most important (second-three) solutions are establishment of hisbah (or supervisory) institution (0.0324), establishment of obligatory zakat system (0.0308), and idle assets distribution (0.0308). Other important solutions to financial crisis are encouragement to give infaq \& shadaqah or charity (0.0307), capital flow management (0.0296), establishment of Islamic free/fair trade area among OIC member countries (0.0296), and credibility of government and private officials (0.0289).

In summary, solutions to financial crisis which stand out are STABLE \& JUST MONETARY SYSTEM, especially the prohibition of maysir and ribā; EXTERNAL CONTROL, especially Islamic economic union, capital flow management and Islamic free trade area; GOOD GOVERNANCE, especially establishment of hisbah institution and credibility; SUSTAINABLE \& JUST FISCAL SYSTEM, especially obligatory zakah system and idle asset distribution; and BEHAVIOR CONTROL, especially encouragement of infaq and shadaqah.

\subsection{Recommendation}

Repeated financial crises in countries adopting conventional economic system could be prevented or (at least) lessened by gradually adopting Islamic economic and finance laws and regulations, partly or fully, especially the main pillars of Islamic financial system, namely the prohibition of riba (usury or interest), prohibition of maysir (gambling and game of chance or speculation) and prohibition of gharar (excessive uncertainty), in their many forms.

The first controlled main root cause of financial crisis is prohibition of maysir or speculation in all forms, which could be done gradually in short/medium term, so that the prohibition of speculation in all markets, especially in financial markets should become the first priority. The second controlled main root cause of financial crisis is prohibition of of riba or usury or interest, which could also be done gradually in short/medium term, so that all forms of riba could be prohibited in all markets, especially in financial markets. 
At the end, all of the suggested solutions to financial crisis should be implemented gradually in order to systematically and gradually improve the stability of financial system so that financial crisis will not reappear again and again in the future.

\section{REFERENCES}

Ahmed, H. (2001). Exchange Rate Stability: Theory and Policies from an Islamic Perspective. Research Paper, 57. Jeddah: Islamic Development Bank Islamic Research and Training Institute.

Ali, S.S. (2006 \& 2007). Financial Distress and Bank Failure: Lessons from Closure of Ihlas Finans in Turkey. Islamic Economic Studies, $14(1 \& 2)$.

Al-Masri, R.Y. (2009). The Global Financial Crisis: Its Causes and Solutions from an Islamic Perspective. In Islamic Economic Research Center. Issues in the International Financial Crisis from an Islamic Perspective. Jeddah: Scientific Publishing Center King Abdulaziz University.

Ascarya and Iskandar, D. (2013).

Chapra, M.U. (1985). Towards a Just Monetary System. United Kingdom: The Islamic Foundation.

Chapra, M.U. (2008). The Global Financial Crisis: Can Islamic Finance Help Minimize the Severity and Frequency of Such a Crisis in the Future? Paper, Presented at the Forum on the Global Financial Crisis, held at the Islamic Development Bank.

Iqbal, M. and Khan, T. (2004). Financing Public Expenditure: An Islamic Perspective. Occasional Paper, 7. Jeddah: Islamic Research and Training Institute - Islamic Development Bank.

Kahf, M. (2000). Principle, Objectives, and Tools of Market Regulation in Islamic Perspectives. Paper, presented at seminar on Islamic approach to market regulation and economic stability, Tehran, Iran.

Khan, A.A. and Thaut, L. (2008). An Islamic Perspective on Fair Trade. Birmingham, United Kingdom: Islamic Relief Worldwide.

Khan, M.A. (2001). Public Finance in Islam. Islamic Studies, 40(2), pp.227-256.

Laeven, Luc. and Valencia, F. (2012). Systemic Banking Crises Database: An Update. IMF Working Paper, WP/12/163.

Lietaer, B., Ulanowicz, R., and Goerner, S. (2009). Options for Managing a Systemic Bank Crisis. S.A.P.I.EN.S, 2(1).

Meera, A.K.M. and Larbani, M. (2004). The Gold Dinar: The Next Component in Islamic Economics, Banking and Finance. Review of Islamic Economics, 8(1), pp.5-34.

Obaidullah, M. (2005). Islamic Financial Services. Jeddah: Islamic Economics Research Center - King Abdulaziz University.

Oguz, O. and Tabakoglu, A. (1991). An Historical Approach to Islamic Pricing Policy: A Research on the Ottoman Price System and its Application. Journal of King Abdulaziz University: Islamic Economics, 3, pp.63-79. 
Othman, R., Aris, N.A., Azli, R.M., and Arshad, R. (2012). Islamic Banking: The Firewall Against the Global Financial Crisis. The Journal of Applied Business Research, 28(1).

Smolo, E. and Mirakhor, A. (2010). The Global Financial Crisis and Its Implications for The Islamic Financial Industry. International Journal of Islamic and Middle Eastern Finance and Management, 3(4), pp.372-385.

\section{APPENDIX 1: Table 4.1 ANP RESULTS}

\begin{tabular}{|c|c|c|c|c|c|}
\hline Name & Limiting & $\begin{array}{l}\text { Normalized } \\
\text { By Cluster }\end{array}$ & Name & Limiting & $\begin{array}{l}\text { Normalized } \\
\text { By Cluster } \\
\end{array}$ \\
\hline \multicolumn{6}{|l|}{ CRISIS } \\
\hline High Inflation & 0.02266 & 0.13029 & Saving Debt Default & 0.02912 & 0.16746 \\
\hline High Depreciation & 0.02604 & 0.14975 & Stock Market Crash & 0.01551 & 0.08917 \\
\hline C. Account Deficits & 0.02187 & 0.12573 & Recession-Depression & 0.03036 & 0.17459 \\
\hline Bank Run & 0.02835 & 0.16301 & & & \\
\hline \multicolumn{6}{|l|}{ SOLUTIONS } \\
\hline Behavior Control & 0.00512 & 0.17657 & Stable \& Just Monetary Syst. & 0.00607 & 0.20949 \\
\hline External Control & 0.00418 & 0.14428 & Sustainable \& Just Fiscal Syst & 0.00728 & 0.25103 \\
\hline Good Governance & 0.00634 & 0.21863 & & & \\
\hline \multicolumn{3}{|l|}{ BEHAVIOR CONTROL } & \multicolumn{3}{|c|}{ STABLE AND JUST MONETARY SYSTEM } \\
\hline Education-Dakwah & 0.02616 & 0.16438 & Riba Prohibition & 0.03528 & 0.22116 \\
\hline Supervision & 0.02616 & 0.16438 & Gold Money System & 0.02383 & 0.14938 \\
\hline Enforcement & 0.02616 & 0.16438 & Narrow Banking System & 0.02383 & 0.14938 \\
\hline Self Control & 0.02381 & 0.14959 & Maysir Prohibition & 0.03979 & 0.24943 \\
\hline Debt Avoidance & 0.02616 & 0.16438 & Asset Backed Securities & 0.02383 & 0.14938 \\
\hline Infaq \& Shadaqah & 0.03070 & 0.19288 & Debit Card & 0.01297 & 0.08128 \\
\hline \multicolumn{3}{|c|}{ EXTERNAL CONTROL } & \multicolumn{3}{|c|}{ SUSTAINABLE \& JUST FISCAL SYSTEM } \\
\hline Disaster \& Crisis Mgt. & 0.01967 & 0.12388 & Obligatory Zakah System & 0.03079 & 0.19242 \\
\hline Fair International Trade & 0.01967 & 0.12388 & Idle Asset Distribution & 0.03079 & 0.19242 \\
\hline Capital Flow Mgt. & 0.02960 & 0.18648 & Islamic Tax System & 0.02757 & 0.17229 \\
\hline Islamic FTA & 0.02960 & 0.18648 & Balanced Budget & 0.02789 & 0.17429 \\
\hline Islamic Economic Union & 0.03415 & 0.21513 & Inventory Management & 0.01860 & 0.11623 \\
\hline Intl. Gold Standard & 0.02606 & 0.16415 & PLS Sukuk & 0.02438 & 0.15235 \\
\hline \multicolumn{3}{|l|}{ GOOD GOVERNANCE } & \multirow{7}{*}{ PLS SUKUK } & & \\
\hline Transparency & 0.02831 & 0.17731 & & & \\
\hline Credibility & 0.02886 & 0.1808 & & & \\
\hline Accountability & 0.02431 & 0.15225 & & & \\
\hline Internal Control & 0.02141 & 0.13413 & & & \\
\hline Hisbah-Institution & 0.03245 & 0.20325 & & & \\
\hline Right Man-Place & 0.02431 & 0.15225 & & & \\
\hline
\end{tabular}

